\title{
開削トンネルの応答値算定に用いる応答震度法 の解析精度に関する検討
}

\author{
川西 智浩 1 ・清野 純史 2 ・西山 誠治 3 \\ 1正会員 京都大学大学院工学研究科助教（† $615-8530$ 京都市西京区京都大学桂船井交流センター） \\ E-mail:kawanishi.tomohiro.6s@kyoto-u.ac.jp \\ 2正会員 京都大学大学院工学研究科教授 （† $615-8540$ 京都市西京区京都大学桂Cクラスター） \\ E-mail:kiyono@quake.kuciv.kyoto-u.ac.jp \\ 3正会員 (株)日建設計シビル 技術開発部（テ541-8528 大阪市中央区高麗橋4-6-2） \\ E-mail:nishiyama@nikken.co.jp
}

\begin{abstract}
地下鉄開削トンネルの耐震設計にあたっては，静的解析法の一種である応答変位法が一般的に用いられ ているが, 地盤ばねの算定精度などに課題を有している. 一方, 周辺の地盤をFEMでモデル化する解析手 法としては，動的解析法と静的解析法を用いることができるが，特に開削トンネルの破壊形態を推定する 場合には，FEM系の静的解析法を用いることも有効であると考えられる. 本研究では，FEM系静的解析法 の一つである応答震度法を用いる場合について，その作用の設定方法を変えた解析的検討を行い，動的解 析法の結果と比較することにより，応答震度法におけるより精度の高い作用の設定方法について検討する.
\end{abstract}

Key Words : cut and cover tunnel, ground response acceleration method, FEM analysis, soil nonlinearity

\section{1. はじめに}

地下鉄開削トンネルにおいて而震設計を実施する場合 には，一般にトンネル各部材の曲率などの応答值を算定 し，材料特性などから定まる限界值を比較する「応答值 の算定」の他に，トンネルがせん断破壊することを防止 するため，曲げ破壊先行になっていることを確認する

「破壊形態の推定」も行う必要がある。また，「応答值 の算定」においては，別途設定した設計地震動を 1.0 倍 とした場合の解析を実施し，応答值を算出することにな るが，兵庫県南部地震における大開駅の事例からもわか るように，中柱などの開削トンネル部材がせん断破壊す るとトンネル全体系の崩壞につながる可能性があるため, 「破壊形態の推定」においては, 設計地震動1.0倍の場 合だけでなく，1.0倍までに至る全ステップや，1.0倍を 超える地震動に対しても曲け破壊先行となることを確認 し，設計で想定しているレベル以上の地震動が発生して もトンネル全体系が崩壊する可能性をできるだけ少なく ようにしている.

したがって，開削トンネルの破壊形態を推定するにあ たっては, 設計地震動レベルを数段階に分けてその都度
動的解析を実施することも考えられるが，どの程度の変 形が発生した場合にどの部材から損傷するかを逐一追跡 するという目的，および設計上の煩雑さを避けるという 目的から，実務設計ではこれらの問題を解消できる静的 解析法を実施することが現実的な方法である.

地下鉄開削トンネルの静的解析法としては，周囲の地 盤を地盤ばねでモデル化した応答変位法を用いることが 一般的である.これは，トンネルの寸法などが設計段階 で変更になっても地盤ばねの再設定が容易であるなど, 設計実務においての利便性によるところが大きい，地盤

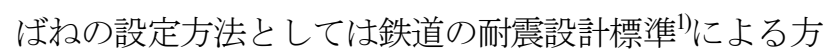
法や駐車場の設計指針 ${ }^{2}$ による方法が挙げられるが，地 盤ばねの算定精度に課題を有している3ふなと。一方，周囲 の地盤をFEMでモデル化した静的解析法を用いることも 可能であり，代表的な手法としては，応答震度法)や FEM応答変位法5)などが挙げられる。これらの手法は， トンネル寸法が変更になった場合には周囲の地盤も含め てメッシユ構築を再度実施する必要がある等の設計上の 問題点はあるが，地盤ばねの算定精度の問題は解消でき るため, 破壊形態の推定において静的解析を実施する際 には比較的精度の高い手法であると考えられる. 


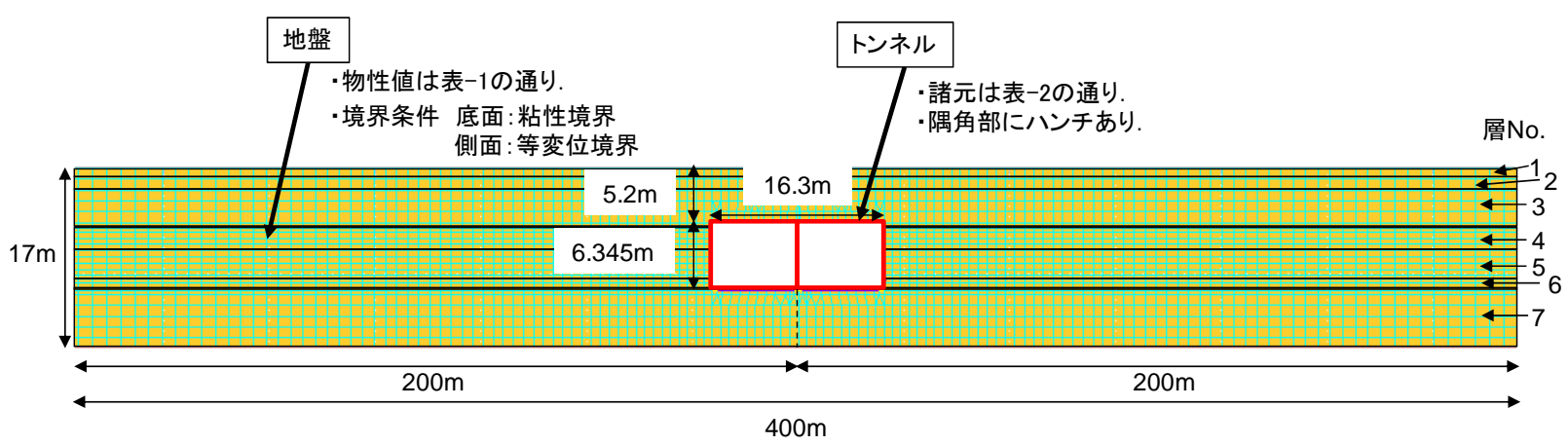

図-1 構造物・地盤モデル

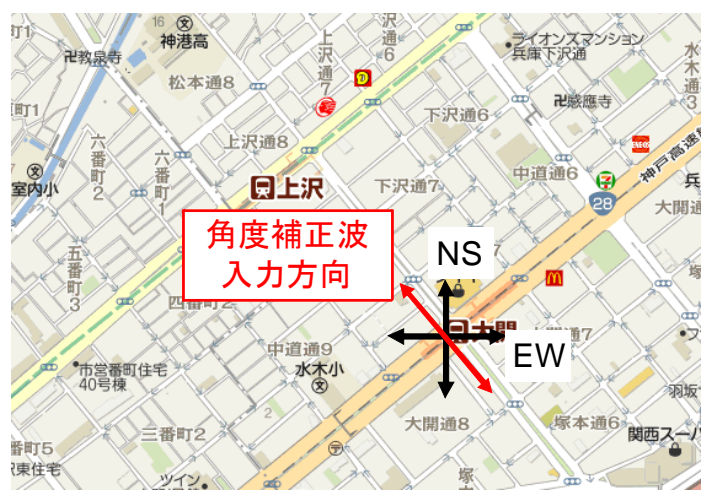

図-2 解析対象とした大開駅の周辺地図(Yahoo!より)

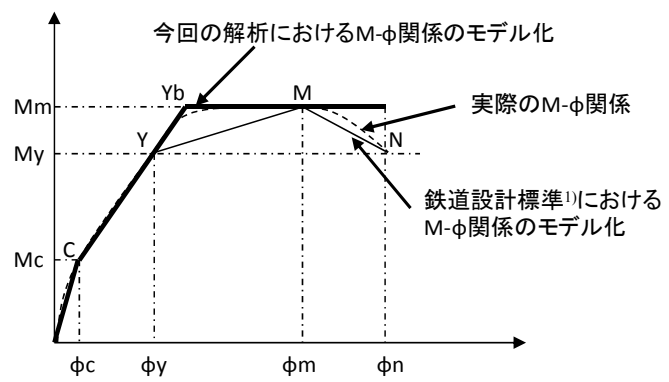

図-3＼cjkstart構造物の非線形特性のモデル化

本検討では，FEM系静的解析法の一つである応答震度 法を対象とした開削トンネルの静的解析における，解析 精度に関する一考察を行う。応答震度法は，トンネル部 材および周囲の地盤の各節点に，地震時の加速度を静的 に作用させてトンネルの応答を算定する方法であるが, その加速度の設定や周囲の地盤の非線形性の考慮などに よって応答解析結果は異なるものとなり, 場合によって は精緻な解析法である動的解析法の応答とはかなりの差 となってしまうため, 周囲の地盤をFEMでモデル化した ことによるメリットを打ち消してしまうことにもなりか ねない.

そこで本検討では，応答震度法における作用（加速 度）や地盤の非線形性の設定方法を変えた検討を実施し， 動的解析法における解析結果と比較することにより，こ れらの要素が応答震度法の精度に及ぼす影響について検 討を行うこととした.
表-1 地盤の物性值

\begin{tabular}{c|c||c|c|c|c}
\hline $\begin{array}{c}\text { 層 } \\
\text { No. }\end{array}$ & 土層種別 & $\begin{array}{c}\text { 層厚 } \\
(\mathrm{m})\end{array}$ & $\begin{array}{c}\text { 単位体 } \\
\text { 積 } \\
\text { 重量 } \\
\left(\mathrm{kN} / \mathrm{m}^{3}\right)\end{array}$ & $\begin{array}{c}\text { 平均せ } \\
\text { ん断 } \\
\text { 弹性波 } \\
\text { 速度 }(\mathrm{m} / \mathrm{s})\end{array}$ & $\begin{array}{c}\text { ポア } \\
\text { ソン } \\
\text { 比 }\end{array}$ \\
\hline \hline 1 & 粘性土 & 1.000 & 16 & 100 & 0.49 \\
\hline 2 & 粘性土 & 1.100 & 16 & 100 & 0.49 \\
\hline 3 & 砂質土 & 3.500 & 18 & 140 & 0.49 \\
\hline 4 & 砂質土 & 2.600 & 18 & 170 & 0.49 \\
\hline 5 & 粘性土 & 2.470 & 16 & 190 & 0.49 \\
\hline 6 & 砂質土 & 0.875 & 18 & 190 & 0.49 \\
\hline 7 & 粘性土 & 5.455 & 16 & 240 & 0.49 \\
\hline
\end{tabular}

表-2 トンネルの諸元

\begin{tabular}{c|cc}
\hline 単位体積重量 & \multicolumn{2}{c}{$24\left(\mathrm{kN} / \mathrm{m}^{3}\right)$} \\
\hline 弾性係数 & & $30.7(\mathrm{GN})$ \\
\hline & 上床版 : & $0.80(\mathrm{~m})$ \\
& 下床版 : & $0.85(\mathrm{~m})$ \\
部材厚さ & 側壁 : & $0.70(\mathrm{~m})<$ 上方 $>$ \\
& & $0.85(\mathrm{~m})<$ 下方 $>$ \\
& 中柱 : & $0.40(\mathrm{~m}) \times$ 奥行き $1.0(\mathrm{~m})$ \\
& & $<2.5(\mathrm{~m})$ 間隔 $>$ \\
\hline
\end{tabular}

表-3 GHE-S モデルのパラメータ

\begin{tabular}{c||c|c|c|c}
\hline & $\gamma_{10}$ & $\mathrm{G}_{\min } / \mathrm{G}_{\max }$ & $\beta_{\mathrm{p}}$ & $\mathrm{h}_{\max }$ \\
\hline \hline 砂質土 & 0.0015 & 0.35 & 1.31 & 0.21 \\
\hline 粘性土 & 0.013 & 0.1 & 1.29 & 0.19 \\
\hline
\end{tabular}

\section{2. 解析手法}

\section{（1）解析に用いたモデル}

本研究において解析に用いた構造物および地盤モデル を図-1〜図-3および表-1〜表-3に示す. 対象としたのは 兵庫県南部地震において中柱のせん断破壊により崩壊し た大開駅における 1 層 2 径間の開削トンネルとその周辺 地盤である．構造物については文献6)7)を参考にトンネ ル各構成部材をモデル化し，鉄道の耐震設計標準 ${ }^{1)}$ を参 考にその非線形性を考慮することとした．ただし，鉄道 の耐震設計標準におけるテトラリニア型モデルは，Y点 


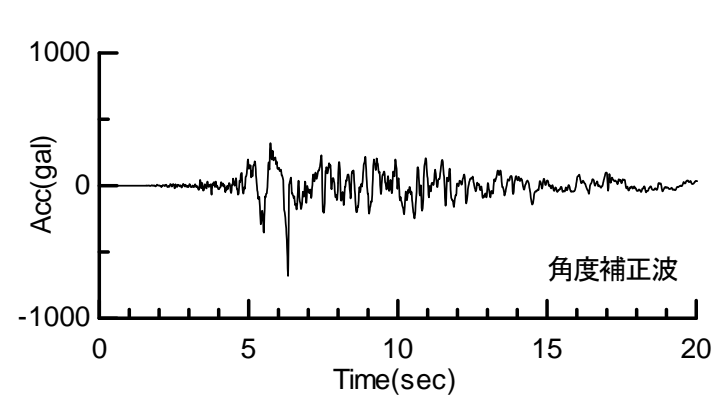

図-4 入力地震波

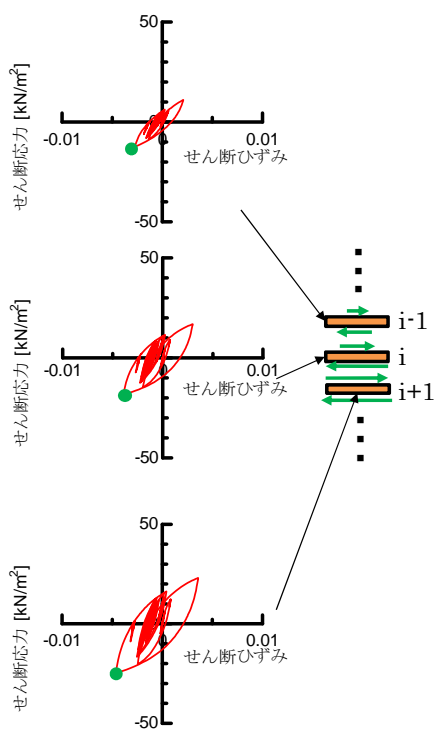

表-4 解析ケース

\begin{tabular}{|c|c|c|c|}
\hline $\begin{array}{c}\text { 応答 } \\
\text { 解析法 }\end{array}$ & Case No. & 地盤 & 地震作用の設定 \\
\hline $\begin{array}{l}\text { 動的 } \\
\text { 解析 } \\
\end{array}$ & - & 非線形 & $\begin{array}{c}\text { 地震波を } \\
\text { 底面から入力 }\end{array}$ \\
\hline \multirow{3}{*}{$\begin{array}{l}\text { 応答 } \\
\text { 震度法 }\end{array}$} & Casel & 非線形 & \multirow{2}{*}{$\begin{array}{c}\text { 動的解析における着目時 } \\
\text { 刻の加速度を各対応深さ } \\
\text { に入力 }\end{array}$} \\
\hline & Case2 & 等価線形 & \\
\hline & Case3 & 非線形 & 図-5参照 \\
\hline
\end{tabular}

(1)最大せん断応力 (○)を抽出

$\left(\tau_{1}, \cdots, \tau_{i}, \tau_{i+1}, \cdots\right)$

(2)せん断応力と加速度の関係式を層ごとに構築

$\tau_{i+1}=\tau_{i}+a_{i} \cdot \gamma_{i} \cdot h_{i}$

$\tau \quad:$ せん断応力

$a:$ 加速度

$\gamma \quad:$ 単位体積重量

$h$ : 層厚

(3)(2)の方程式を解いて算出した各深さ位置の

加速度 $a_{i}$ を対応する各深さのメッシュ節点に

かけて応答震度法の解析を実施。

図-5＼cjkstart作用させる加速度の設定

（軸方向鉄筋の降伏点）とM点（最大耐力点）を結ぶこ とにより降伏点後の岡性低下を安全側に評価しているが, 本検討では図-3に示すように，C点（ひび割れ点）とY 点を結ぶ線およびM点を水平に延長した線の交点（Yb 点）を剛性の折れ点とし， C点，Yb点，M点を結ぶトリ リニア型でモデル化することとした.

一方，地盤についても文献67)を参考に地層構成をモ デル化し，その非線形性をGHE-Sモデル8)を用いてモデ ル化した. GHE-Sモデルにおける骨格曲線，除荷時の接 線岡性，およびh- $\gamma$ 関係を式(1)〜(3)にそれぞれ示す.

$$
\begin{gathered}
C_{1}(x)=\frac{C_{1}(0)+C_{1}(\infty)}{2}+\frac{C_{1}(0)-C_{1}(\infty)}{2} \cdot \cos \left\{\frac{\pi}{\alpha / x+1}\right\} \\
C_{2}(x)=\frac{C_{2}(0)+C_{2}(\infty)}{2}+\frac{C_{2}(0)-C_{2}(\infty)}{2} \cdot \cos \left\{\frac{\pi}{\beta / x+1}\right\} \\
\frac{G_{0}}{G_{\max }}=\frac{1-G_{\min } / G_{\max }}{1+\gamma / \gamma_{r 0}}+\frac{G_{\min }}{G_{\max }} \\
h=h_{\max }\left(1-G / G_{0}\right)^{\beta_{p}}
\end{gathered}
$$

文献 8)では，標準パラメータとして $C_{1}(0)=1.0$ ， $C_{2}(0)=0.83, C_{1}(\infty)=0.17, C_{2}(\infty)=2.5, \alpha=2.86, \beta=3.229$
が与えられており，本研究でもこの值を用いる．また， その他のパラメータについては土層種別毎に表-3に示す 值を用いる.

\section{（2） 入力地震動}

本検討における動的解析では，兵庫県南部地震におい てポートアイランドGL-82m位置で観測された地震波を 入力地震動として用いることとした. なお，図-2に示す ように大開駅の解析対象地点は線路方向が東西方向から 傾いているので，地図から角度を読夕取り，角度を補正 した地震波を解析に用いることとした（図-4）。

\section{(3) 解析ケース}

本検討における解析ケースを表-4に示す．本検討では， 動的解析（1 ケース）のほか，3 ケースの応答震度法

（Case1～Case3）を実施する. 本検討ではまず動的解析 を実施し，トンネル上下床版間に対応する深さ（深さ -5.20m〜-11.545m) における，自然地盤（トンネルか ら十分離れた位置) の相対変位が最大となる時刻に着目 し，その時刻におけるトンネルの応答值を算出するとと もに，自然地盤における加速度，せん断応力およびせん 断ひずみを抽出する.

次に，応答震度法におけるCase1およびCase2では，上 


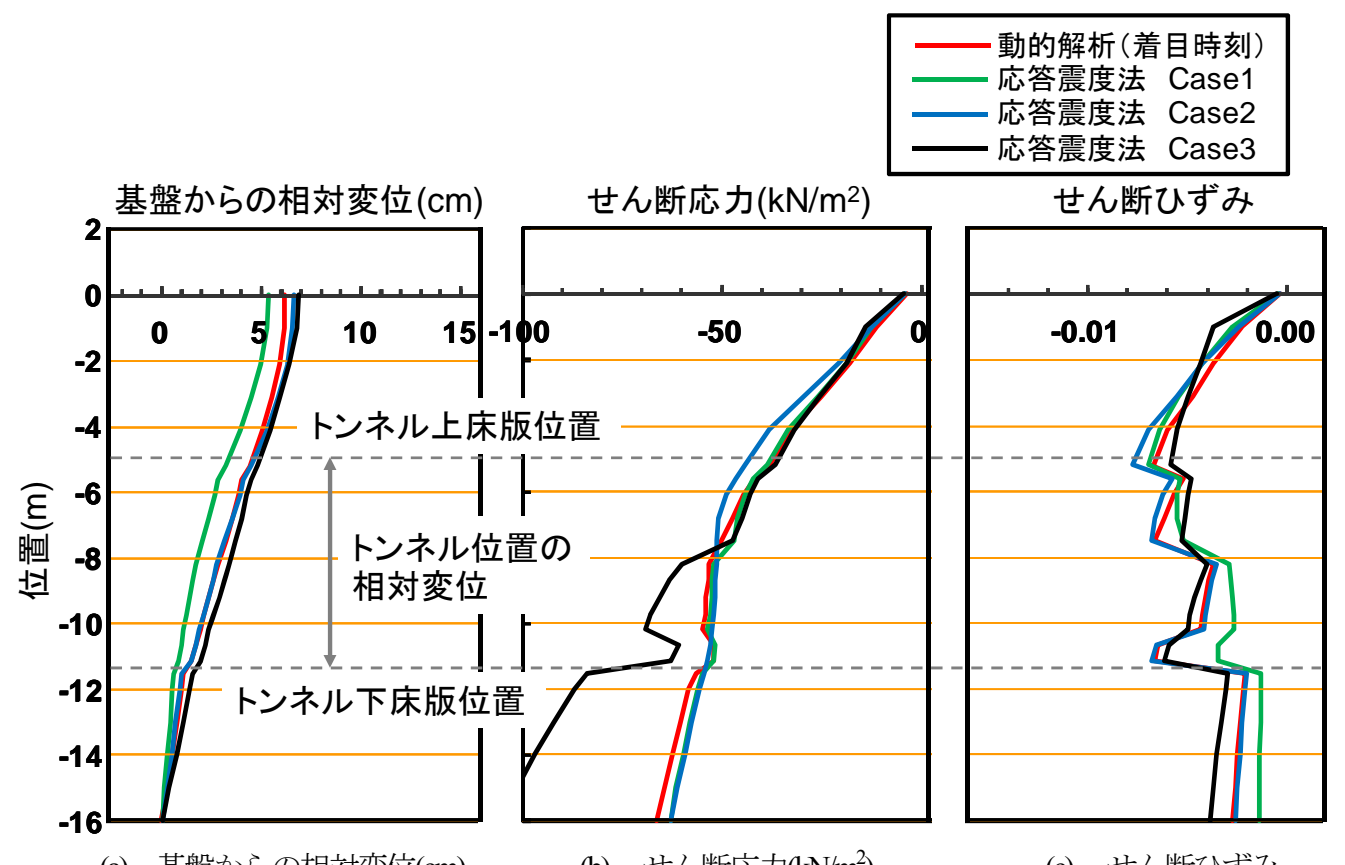

(a) 基盤からの相対変位(cm)

(b) せん断応力 $\left(\mathrm{kN} / \mathrm{m}^{2}\right)$

(c) せん断ひずみ

図-6 自然地盤の応答值の比較

表-5 トンネル上下床版位置における地盤の相対変位の比較

\begin{tabular}{c|c||c}
\hline $\begin{array}{c}\text { 応答 } \\
\text { 解析法 }\end{array}$ & Case No. & 相対変位 $(\mathrm{cm})$ \\
\hline \hline 動的解析 & - & 3.36 \\
\hline \multirow{2}{*}{$\begin{array}{c}\text { 応答 } \\
\text { 震度法 }\end{array}$} & Case1 & 2.63 \\
\cline { 2 - 3 } & Case2 & 3.51 \\
\cline { 2 - 3 } & Case3 & 3.26 \\
\hline
\end{tabular}

記の動的解析において抽出した加速度を対応する各深さ 位置にかける．なお，Case1では地盤を動的解析と同様 非線形で設定し，一方Case2では，着目時刻におけるせ ん断応力およびせん断ひずみからせん断岡性を算出し， そのせん断岡性を有する等価線形モデルで地盤をモデル 化することとした。

最後にCase3では，地盤はCasel と同様に非線形とする が，作用させる加速度の值をCase1，Case2とは変えるこ ととする. 作用させる加速度の設定方法を図-5に示す. まず，Case1やCase2のように着目時刻における值ではな く最大せん断応力を取り出し, 各せん断応力が再現でき るように, 各地盤要素の重量, 加速度およびせん断応力 のつり合い式をたて，それを解くことにより算出した加 速度を，各深さ位置にかけることとした。

\section{3. 自然地盤の応答}

\section{(1) 解析結果}

自然地盤位置における基盤からの相対変位，せん断応
力およびせん断ひずみをケース毎に比較した結果を図一 に示寸，動的解析は着目時刻における値，応答震度法に ついては最終ステップ（荷重1.0倍に相当）の值を示し ている．また表-5には，トンネル上下床版位置に対応す る深さ間での地盤の相対変位を比較した結果を示す。

Case1における相対変位が他のケースに比べて小さく なっていることがわかる. Case1のせん断ひずみに着目 すると，特に深い位置での值が他のケースと比べて小さ くなっており，これが相対変位の大小に影響を及ぼした ものと思われる. Case2やCase3の相対変位およびせん断 ひずみは，動的解析の結果と概ね等しくなっている.

一方，せん断応力に着目寸ると，特に深い位置におけ るCase3の值が他のケースに比べて大きくなっており， その他のケースは動的解析の結果と概初同程度の值にな っていることがわかる.

\section{(2) 考察}

(1)に示した解析結果について考察するため，代表的 な深さ位置における地盤の応力-ひずみ関係と, 対象ス テップにおける応力-ひずみの值を示したものを図-7に 


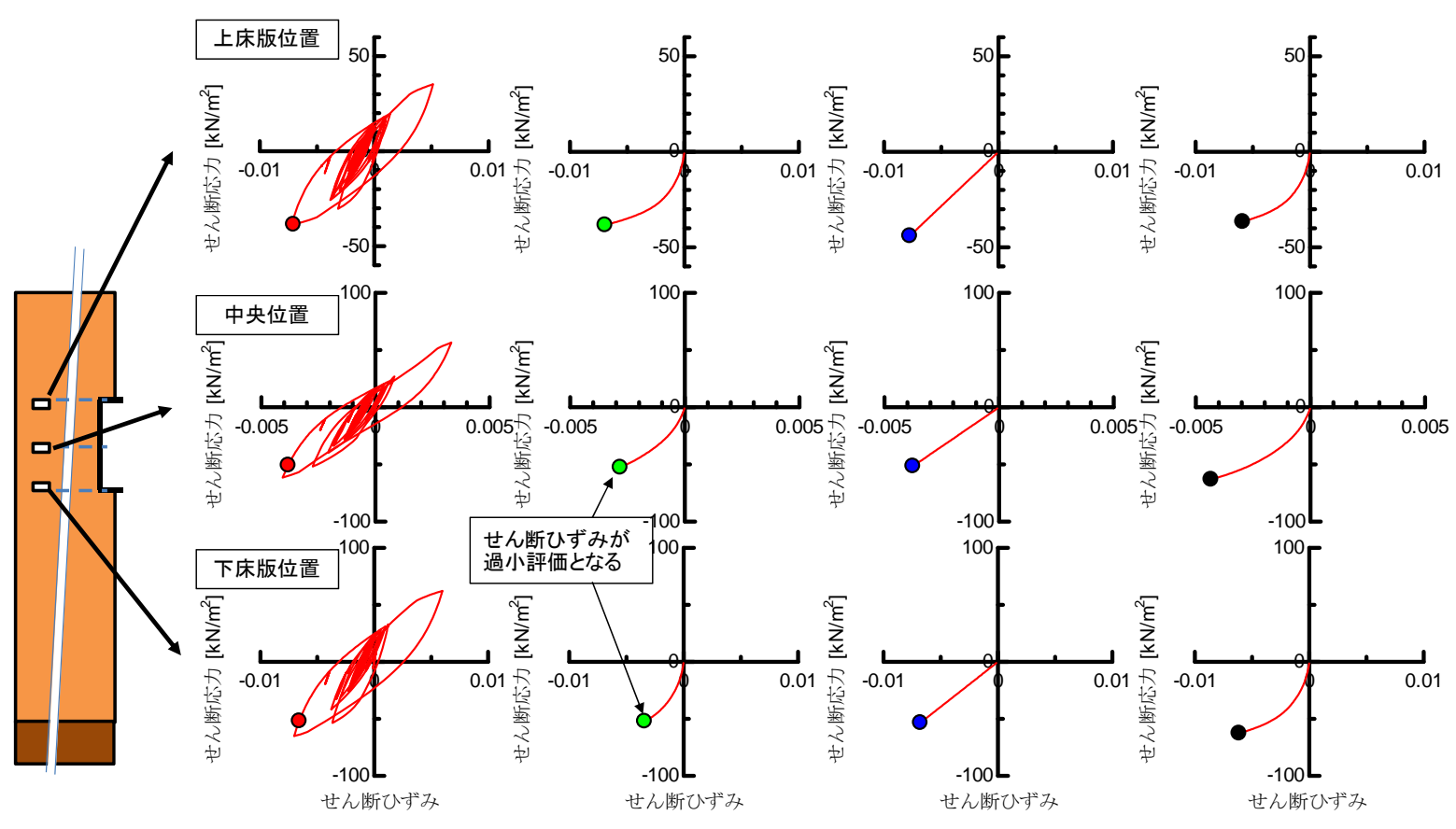

(a) 動的解析

(b) 応答震度法 Case1

(c) 応答震度法 Case2

(d) 応答震度法 Case3

図-7 代表深さ位置における自然地盤の応力ひず夕関係

(○は着目ステップの值＜動的解析 : 着目時刻, 応答震度法 : 最終ステップ>)

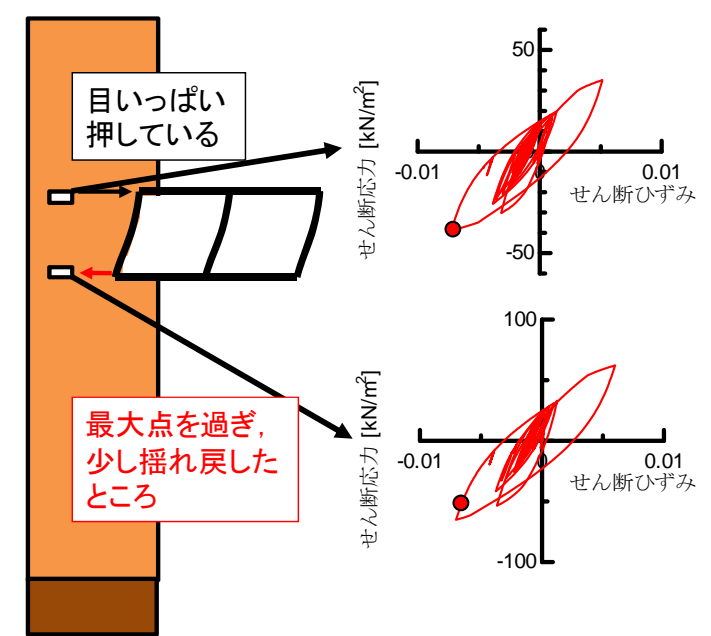

図-8 着目時刻での動的解析の応力-ひずみ関係イメージ

示寸. 動的解析の結果に着目寸ると, 着目時刻における 応力-ひずみ位置は, トンネル上床部付近の深さ位置で はせん断応力・せん断ひずみの最大值付近となっている のに対し，トンネル下床部付近の深さ位置では最大点を 過ぎ，履歴曲線に沿って少し折り返した位置になってい ることがわかる。つまり，地震動は下から上へ伝播する ため, トンネル上部が最大点付近まで押されているタイ ミングではトンネル下部は摇れ戻されており, 結果とし て上下床版位置の相対変位がこのタイミングで最大とな っている（図-8）。一方，応答震度法では，骨格曲線上 を辿って静的に載荷することになるので, 最終ステップ で目指す応力ひずみ位置が動的解析と異なり, せん断
応力が概ね同程度の骨格曲線上の点となるため, 特に深 い位置でのせん断ひずみが動的解析の場合と比べて小さ くなってしまう。地盤を等価線形にしたCase2は最終ス テップの応力ひずみのみを目指しているためこのよう な差が生じず，また，最大せん断ひずみと，動的解析の 着目時刻におけるせん断ひずみの值にそれほど差がない ため, Case3では最大せん断応力の再現に重きを置いて いるにも関わらず，Case1に比べると動的解析に近い結 果になっていると考えられる.

ただし, Case3では着目時刻ではなく, 各深さにおけ る最大せん断応力を抽出して加速度に換算しているため, せん断応力は特に深い位置で過大評価となる. また，地 震波が下方から上方へと伝播する性質上，せん断応力が 最大となる時刻は各深さ位置で異なるため, 変形や応力 のモードも動的解析とは異なってくることから，トンネ ルの応答評価にあたって悪影響を及ぼすことも懸念され る.

\section{4. トンネルの応答}

\section{(1) トンネルの変形の比較}

トンネルの変形を比較した結果を図-9に，上下床版間 の相対変位（トンネル中柱位置）を比較した結果を表-6 に，それぞれ示す，なお図-9においては，地盤の変形量 自体が異なる影響を打ち消すため, 各トンネルの下床部 


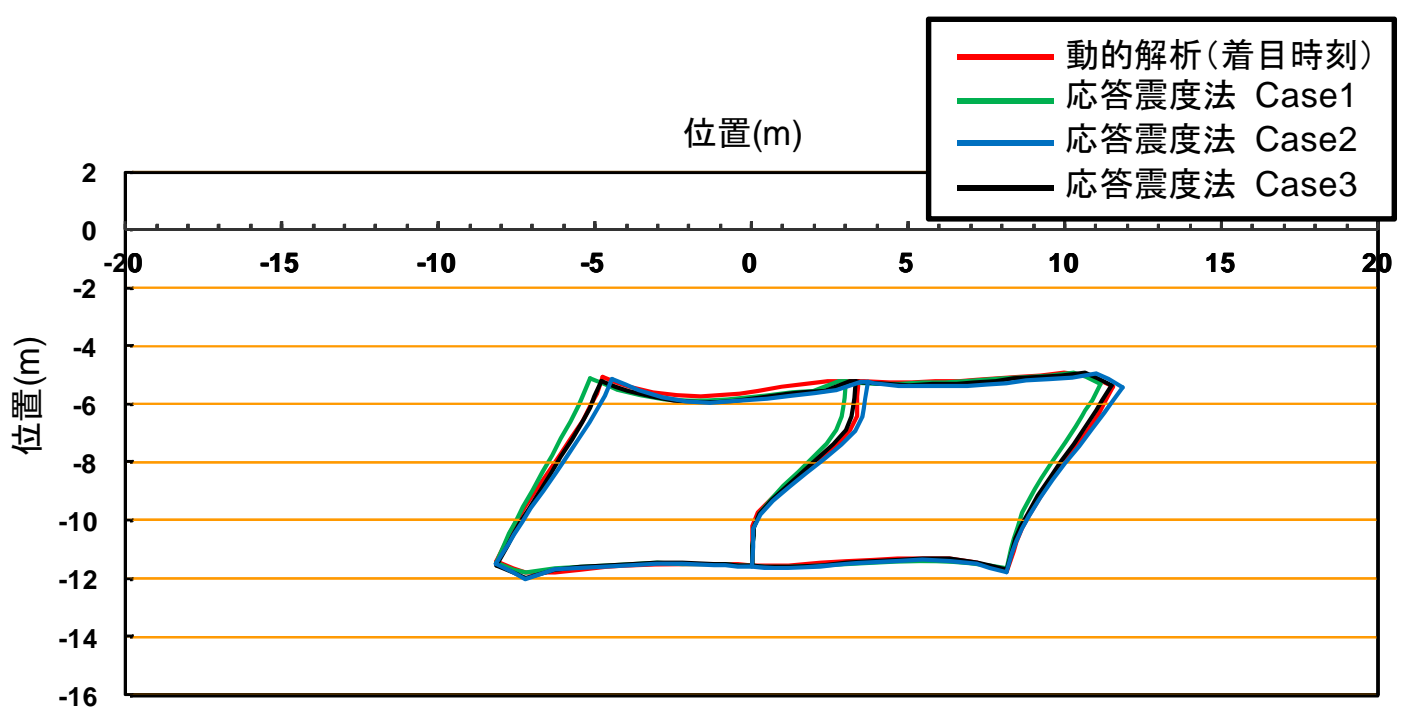

図-9＼cjkstart着目時刻におけるトンネルの変形の比較 （地震時増分を 100 倍に拡大表示）

表-6 上下床版間相対変位 (中柱位置) の比較

\begin{tabular}{c|c||c}
\hline $\begin{array}{c}\text { 応答 } \\
\text { 解析法 }\end{array}$ & Case No. & 相対変位 $(\mathrm{cm})$ \\
\hline \hline $\begin{array}{c}\text { 動的 } \\
\text { 解析 }\end{array}$ & - & 3.41 \\
\hline \multirow{2}{*}{$\begin{array}{c}\text { 応答 } \\
\text { 震度法 }\end{array}$} & Case1 & 3.00 \\
\cline { 2 - 3 } & Case2 & 3.71 \\
\cline { 2 - 3 } & Case3 & 3.33 \\
\hline
\end{tabular}

中央位置における変位を0とした相対変位で表示してお り，また地震時増分変位を100倍に拡大してトンネルの 変形を表している.

動的解析と応答震度法の結果を比較すると，地盤を非 線形とし着目時刻の加速度を用いたCase1の相対変位が, 動的解析法よりも小さくなっている. これは3.で述べた ように自然地盤のせん断ひずみが小さく再現されること が影響しているものと考えられ，地盤を非線形とした場 合の応答震度法の取り扱いには注意が必要であることを 示している. 一方, Case2における変位は動的解析に比 べて大きくなっている. Case2は地盤を等価線形で取り 扱っており，最終ステップに至るまでの地盤のせん断剛 性が他のケースに比べて過小評価となるため, 周辺地盤 の抵抗が小さくなり, 変形が大きくなったものと考えら れる，最後に，Case3におけるトンネルの相対変位は動 的解析の結果に比較的近い值となっている. 図-10には, 中柱で最も曲率が大きい位置における部材のM- $\phi$ 関係 を示している. 今回のケースでは, 応答震度法のCase1 のケースのみ降伏点を下回っている，つまり，応答震度 法の精度が部材の損傷程度に影響を及ぼす場合もあるこ

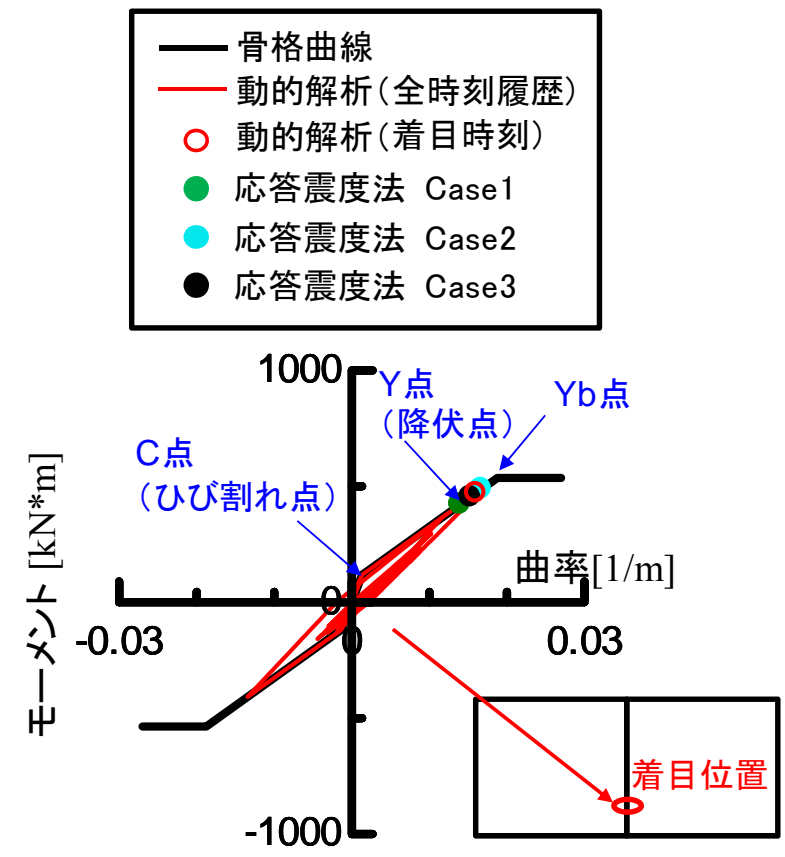

図-10 M- $\phi$ 関係の比較（中柱下部）

とから，応答震度法を用いる場合には，加速度の作用方 法に配慮したり，地盤を等価線形として取り扱う方が卜 ンネルの応答を適切に評価できることがわかった。

ただし，今回対象としたトンネルはトンネルの高さが 比較的低い 1 層 2 径間のトンネルであり, Case3のデメ リットとして3.で指摘したせん断応力が過大評価となる 点, 変形や応力のモードが実際の挙動とは異なる点の影 響が比較的小さくなるようなモデルとなっている．駅部 などのように開削トンネルの高さが今回のモデルよりも 高い場合についての影響検討については今後の課題であ る. 


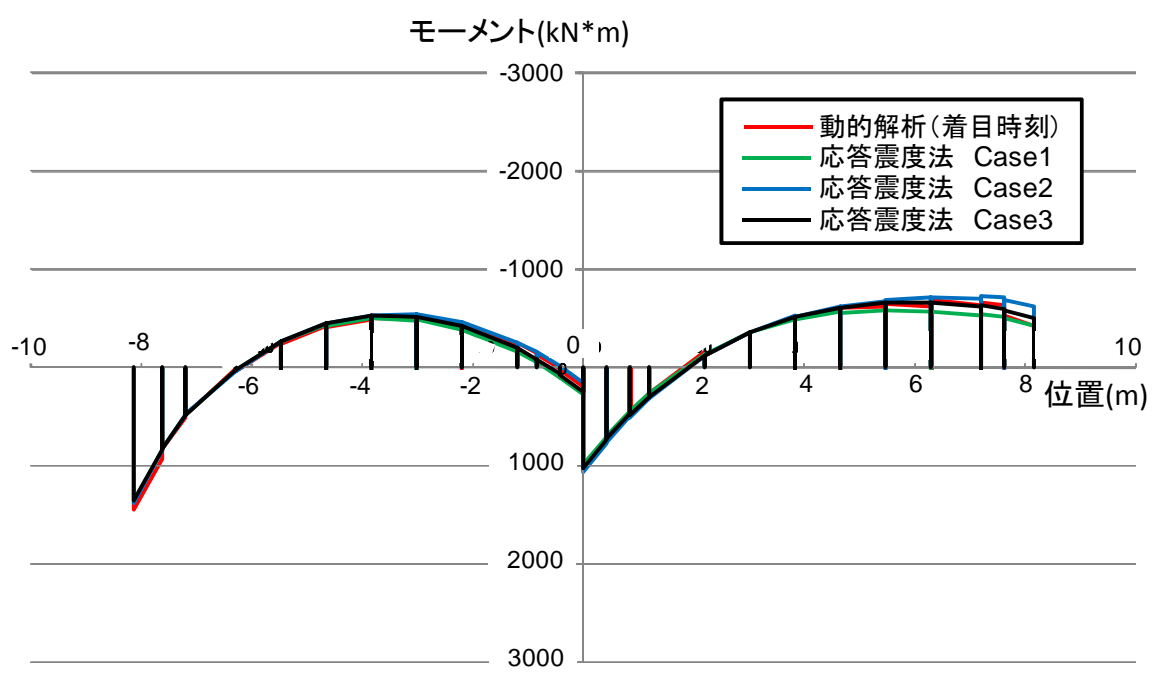

(a) モーメント

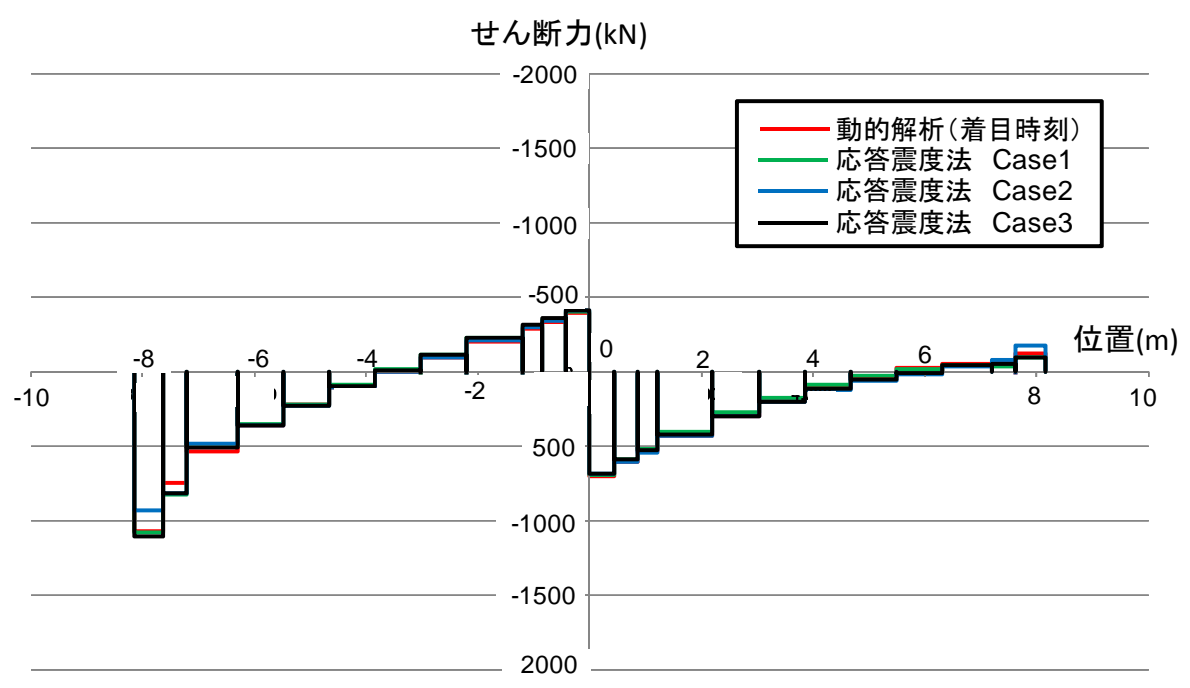

(b) せん断力

図-11 着目時刻におけるトンネルの断面力の比較（下床版）

\section{(2) トンネルの断面力の比較}

開削トンネルの下床版および右側壁において，対象ス テップにおける部材の断面力を比較した結果を図-11,

図-12にそれぞれ示寸．トンネル下床版右側や右側壁下 方のモーメント分布に着目すると，動的解析に比べて Case1のモーメントの值が過小評価となっている. Case1 のように地盤を非線形とした場合に応答震度法を用いる 場合, 相対変位最大の時刻に着目寸ると, 図-8に示した ようにトンネル下床版付近の地盤が摇れ戻された状態に 着目寸ることになり，地盤のひずみが一般に過小評価と なる.これにより，トンネルの応答も小さく算定される ため, 而震評価を実施する上では十分な注意が必要であ る. 一方，せん断力分布については，Case2において下 床版端部のせん断力が他のケースの值と比べて少し差が ある。これは地盤の剛性を等価線形で設定していること
が影響していると考えられるが，この部材は剛と扱って いる部材であり，せん断耐力は十分大きいため，照査結 果に影響が及ぶことはない．また右側壁において動的解 析の結果に対して応答震度法各ケースのせん断力が少し 過小評価となっている.この原因としては動的解析にお ける繰り返し載荷の影響などが考えられるが，今後詳細 な検討が必要である，ただし，Case1におけるモーメン 卜（下床版右側・右側壁下方の部材）が他のケースに比 べてかなり過小評価であった点に比べるとその影響は比 較的小さいものと考えられる．したがって，地盤を等価 線形として応答震度法を実施したり，提案したように作 用させる加速度を修正させて非線形の応答震度法を実施 することにより，トンネルの断面力評価の精度は向上す るものと考えられる. 


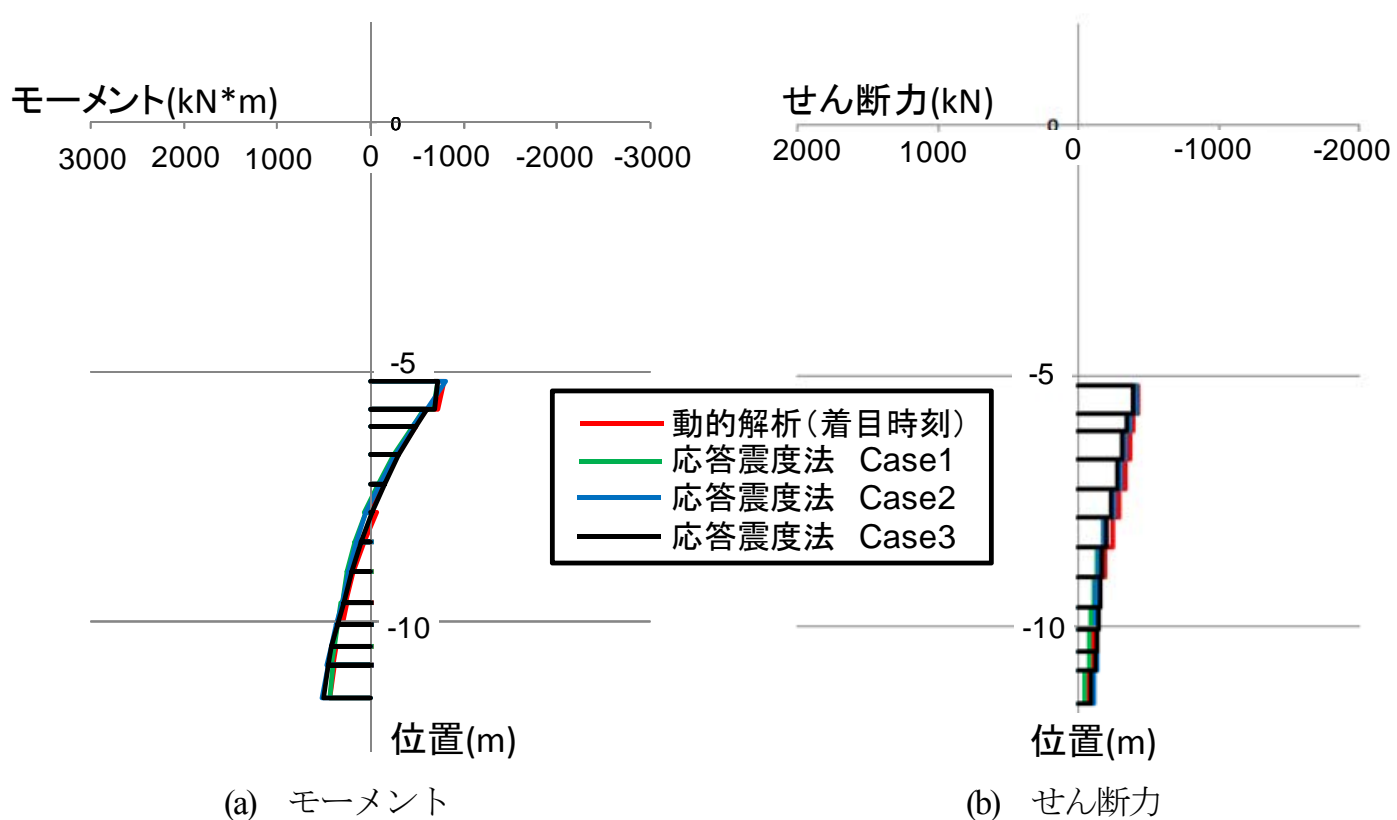

図-12 着目時刻におけるトンネルの断面力の比較（右側壁）

\section{5. 入力地震動レベルが応答震度法の解析精度に 及ぼす影響}

\section{(1) 検討概要および条件}

4.で述べたように，着目時刻の加速度を用いた非線形 の応答震度法では，トンネル下側付近における地盤の摇 れ戻しによる影響によりトンネルの応答が過小評価にな る一方，着目時刻の等価岡性を用いた等価線形型の応答 震度法や，地盤を非線形とし，地盤に作用させる加速度 を最大せん断応力に基づいて修正した応答震度法を用い ることで，応答震度法におけるトンネルの応答や断面力 の算定精度が向上することがわかった。

ただし，地盤の摇れ戻し（履歴曲線の折り返し）や着 目ステップに至るまでの等価せん断岡性の大小がどの程 度トンネルの応答に影響を及ぼすかは，入力地震動の大 きさ，地盤条件，構造物条件等，様々な要因に左右され る. そこで本章では，このうち入力地震動の大きさによ る影響に着目し，図-4に示した入力地震動の最大加速度 を調整して同様の解析を実施することにより，動的解析 と応答震度法の結果を比較し，地震動レベルによる影響 を検討することとする.

具体的には，図-4に示した地震動（最大加速度： 680gal，以下，基準波と呼ぶ。）に対し，最大加速度を $400 \mathrm{gal}$ ，500gal，600gal，基準波(680gal)，750gal，850gal $の$ 計6段階に調整し，2.と同様の手順で動的解析および応 答震度法の解析を実施する. 地盤条件等，その他の条件 は2.の解析と同じとした.

\section{(2) 解析結果}

まず，トンネル上下床版位置に対応する地盤の相対変 位, およびトンネル (中柱位置) の相対変位の算定結果 を表-7および図-13，図-14に示す.

応答震度法Case1 (非線形) に着目すると，3.および4. で述べたように，基準波の場合には動的解析に比べて応 答が過小評価であったが，加速度が小さくなるにつれて， 応答震度法の結果が動的解析に近づいていくことがわか る.これは図-15に示すように，入力加速度が小さい場 合には履歴ループが小さく，履歴曲線の折り返しにより せん断ひずみを過小評価する度合いが，基準波に比べて 小さいためであると考えられる.

次に，応答震度法Case2（等価線形）については，加 速度の増減による動的解析と応答震度法の結果の差異 の影響は比較的少なく，今回のケースでは自然地盤で3 〜 6\%, トンネルで10\%前後過大に評価している. 今回 のケースでは，すべてのケースにおいて自然地盤よりト ンネルの方が相対変位の值が大きくなる傾向があること から，地盤よりもトンネルの方が岡性が弱く，より変形 するモードになっていると考えられるが，Case2では地 盤を等価線形としているために，着目ステップに至るま でのトンネル周辺の地盤抵抗を非線形の場合に比べて弱 めに評価してしまうため，トンネルが地盤非線形の場合 よりも大きく変形してしまい，自然地盤に比べてトンネ ルの相対変位のほうがより過大に評価しているものと思 われる。ただし，その割合は高々 $10 \%$ 程度であり，耐震 の評価結果にほとんど余裕がないような場合を除けば十 分有用であると思われる. 
表-7 入力地震動の最大加速度を変えた場合の地盤およびトンネル相対変位の比較

\begin{tabular}{|c|c|c|c|c|c|c|c|c|c|}
\hline & & \multicolumn{4}{|c|}{ 自然地盤 } & \multicolumn{4}{|c|}{ トンネル(中柱位置) } \\
\hline & & 動的解析 & $\begin{array}{c}\text { 応答震度法 } \\
\text { Case } 1\end{array}$ & $\begin{array}{c}\text { 応答震度法 } \\
\text { Case2 }\end{array}$ & $\begin{array}{c}\text { 応答震度法 } \\
\text { Case3 }\end{array}$ & 動的解析 & $\begin{array}{c}\text { 応答震度法 } \\
\text { Case } 1\end{array}$ & $\begin{array}{c}\text { 応答震度法 } \\
\text { Case2 }\end{array}$ & $\begin{array}{c}\text { 応答震度法 } \\
\text { Case3 }\end{array}$ \\
\hline \multirow{2}{*}{$400 \mathrm{gal}$} & 相対変位 $(\mathrm{cm})$ & 1.22 & 1.31 & 1.29 & 1.44 & 1.38 & 1.47 & 1.47 & 1.57 \\
\hline & 動的解析からの倍率 & & 1.07 & 1.06 & 1.18 & & 1.07 & 1.07 & 1.14 \\
\hline \multirow{2}{*}{$500 \mathrm{gal}$} & 相対変位 $(\mathrm{cm})$ & 1.78 & 1.61 & 1.83 & 2.06 & 1.92 & 1.84 & 2.04 & 2.15 \\
\hline & 動的解析からの倍率 & & 0.90 & 1.03 & 1.16 & & 0.96 & 1.06 & 1.12 \\
\hline \multirow{2}{*}{$600 \mathrm{gal}$} & 相対変位(cm) & 2.58 & 2.15 & 2.66 & 2.72 & 2.68 & 2.44 & 2.89 & 2.79 \\
\hline & 動的解析からの倍率 & & 0.83 & 1.03 & 1.05 & & 0.91 & 1.08 & 1.04 \\
\hline \multirow{2}{*}{ 680gal(基準波) } & 相対変位 $(\mathrm{cm})$ & 3.36 & 2.63 & 3.51 & 3.26 & 3.41 & 3.00 & 3.71 & 3.33 \\
\hline & 動的解析からの倍率 & & 0.78 & 1.04 & 0.97 & & 0.88 & 1.09 & 0.98 \\
\hline \multirow{2}{*}{$750 \mathrm{gal}$} & 相対変位(cm) & 4.05 & 2.81 & 4.20 & 3.70 & 3.93 & 3.22 & 4.31 & 3.73 \\
\hline & 動的解析からの倍率 & & 0.69 & 1.04 & 0.91 & & 0.82 & 1.10 & 0.95 \\
\hline \multirow{2}{*}{$850 \mathrm{gal}$} & 相対変位 $(\mathrm{cm})$ & 4.90 & 3.29 & 5.14 & 4.31 & 4.55 & 3.70 & 5.18 & 4.36 \\
\hline & 動的解析からの倍率 & & 0.67 & 1.05 & 0.88 & & 0.81 & 1.14 & 0.96 \\
\hline
\end{tabular}

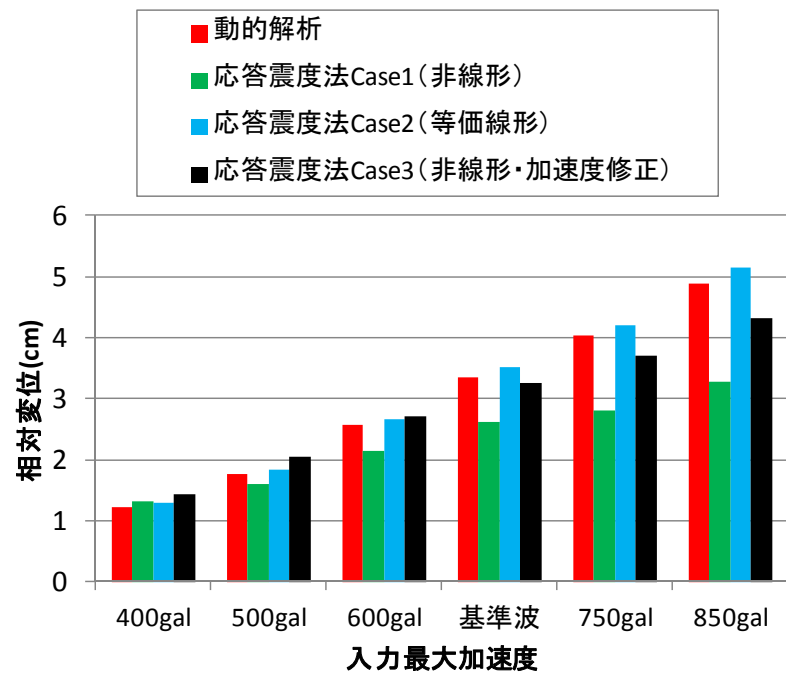

図-13＼cjkstart自然地盤のトンネル上下床版深さ位置の相対変位の比較

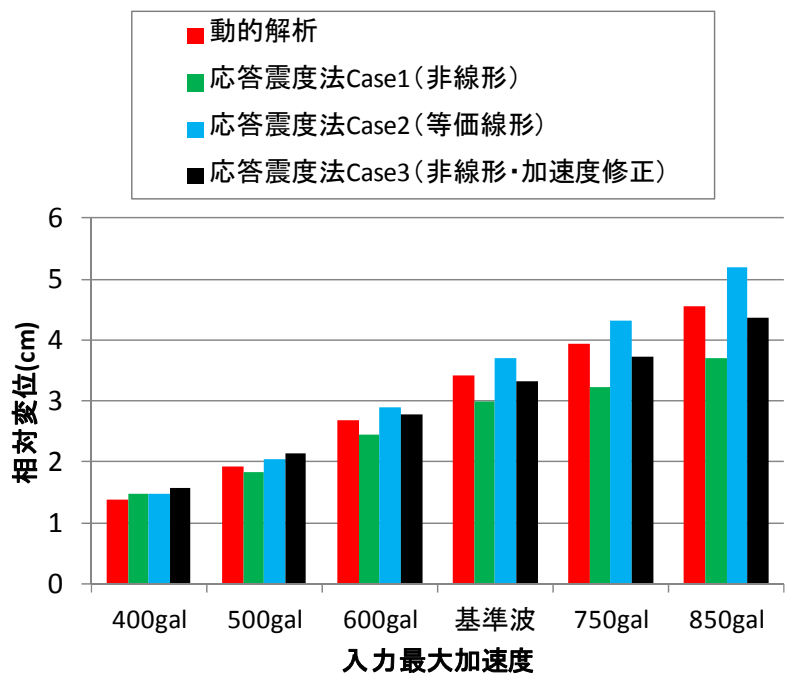

図-14 トンネル (中柱位置) の相対変位の比較
さらに，応答震度法Case3（非線形・加速度を修正す るケース) については，加速度が小さくなるにつれて， 動的解析に比べて変形を少し大きめに評価する傾向が高 くなっていくが，絶対的な変位量自体の差は図-14のグ ラフを見てもわずかであり，応答の評価を行う上では大 きな問題はないと思われる. しかし，逆に加速度を大き く寸ると, 動的解析に比べて自然地盤で10\%前後, トン ネルで5\%程度変形を過小に評価しており, 絶対的な変 位量の差も大きいことがわかる.

これらの解析結果の傾向について考察するため, 最大 加速度850galのケースにおける, 地盤の応力ひずみ関係 を図-16に示寸．地盤の塑性化がかなり進行している下 床版位置の応力ひずみ関係に着目すると, 動的解析に おいて着目時刻直前の履歴曲線が骨格曲線の内側を通っ ており，さらに骨格曲線に達する直前で応力-ひずみ関 係が折り返していることがわかる，これは，正側でいっ たん応力ひずみの最大点に達していることから，GHE$\mathrm{S} モ テ ゙ ル の$ 特性上，反対側の負側においてこの点の対称 点に向かって最大点指向していく途中で再度折り返し, この時刻が自然地盤の相対変位最大時刻になってしまっ たために起こった現象であると考えられる。一般的には
応力-ひずみ関係の最大点と相対変位最大点は同じ符号 側になることが多いと考えられるため，このような問題 が生じる可能性は低いと思われるが，この結果は動的解 析の応力-ひずみ関係にあらかじめ注意して, 応答震度 法の適用を考える必要があることを示唆している.

つまり, 今回のケースではトンネルの変形は動的解析 に比べて $5 \%$ 程度の過小評価に留まっており, 加速度を 最大せん断応力に基づいて修正した応答震度法が十分適 用可能であることが示唆されるが，地盤条件・構造物条 件によっては地盤の履歴形状の影響が大きくなる可能性 もあり，適用には注意が必要であることがわかった。

最後に, 中柱下部における曲率，モーメント（下端 側），せん断力を比較した結果を図-17に示す．応答震 度法Caselについては, 加速度が小さい場合には動的解 析と概ね等しくなっているが，それ以上加速度が大きく なると, 曲率・断面力とも過小評価となる. これはトン ネルの変形と同様, 履歴曲線の折り返しによりせん断ひ ずみを過小評価する度合いの違いによるものと考えられ る. 応答震度法Case2については, どの加速度について も動的解析を良い一致を示しているが，加速度850galの ケースでは，応答がYb点を超えてしまい曲率が急激に 


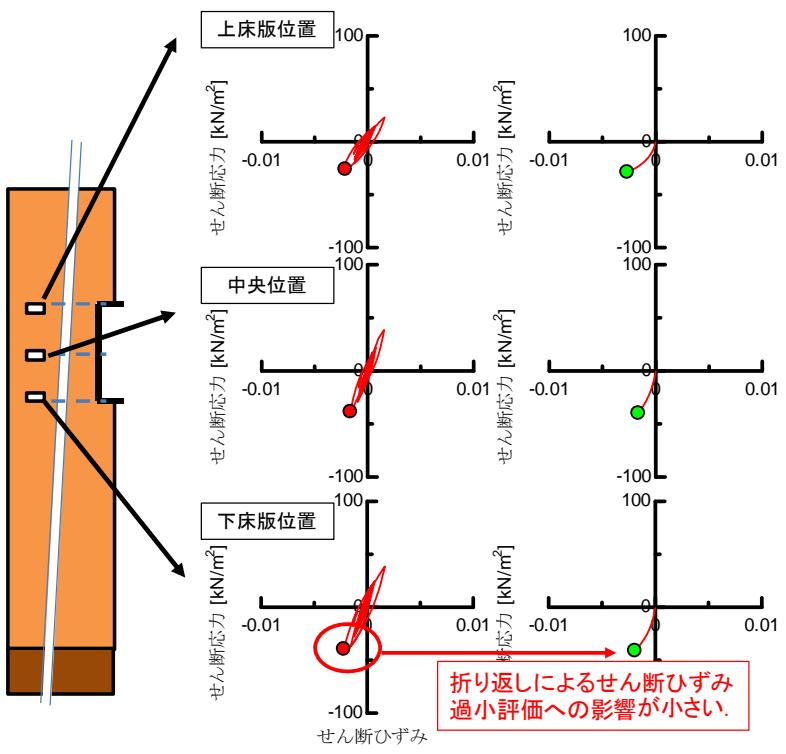

(a) 動的解析 (b) 応答震度法 Casel

図-15 代表深さ位置における自然地盤の応力-ひずみ関係 (最大加速度 : 400gal)
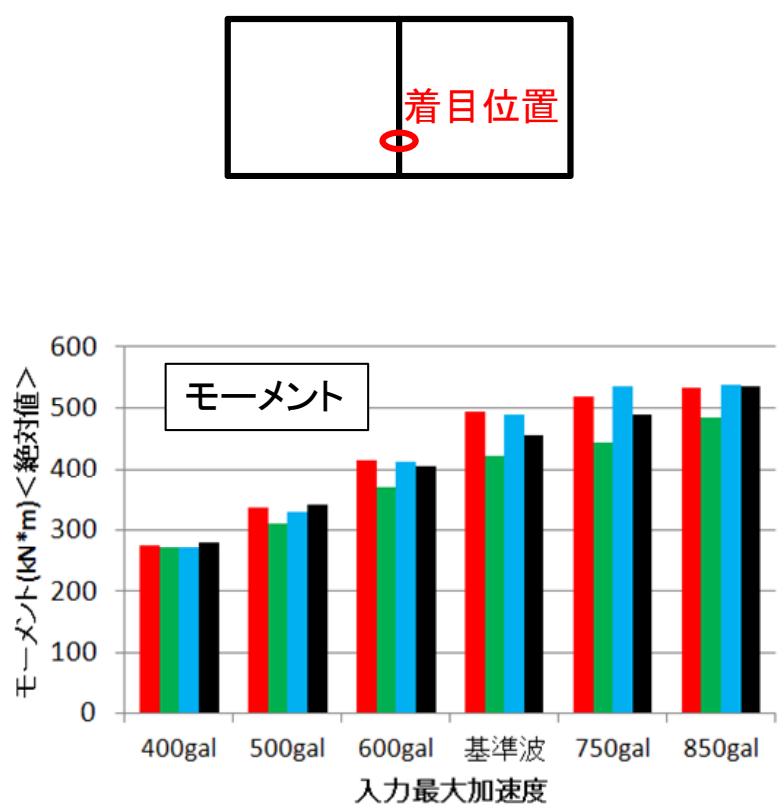

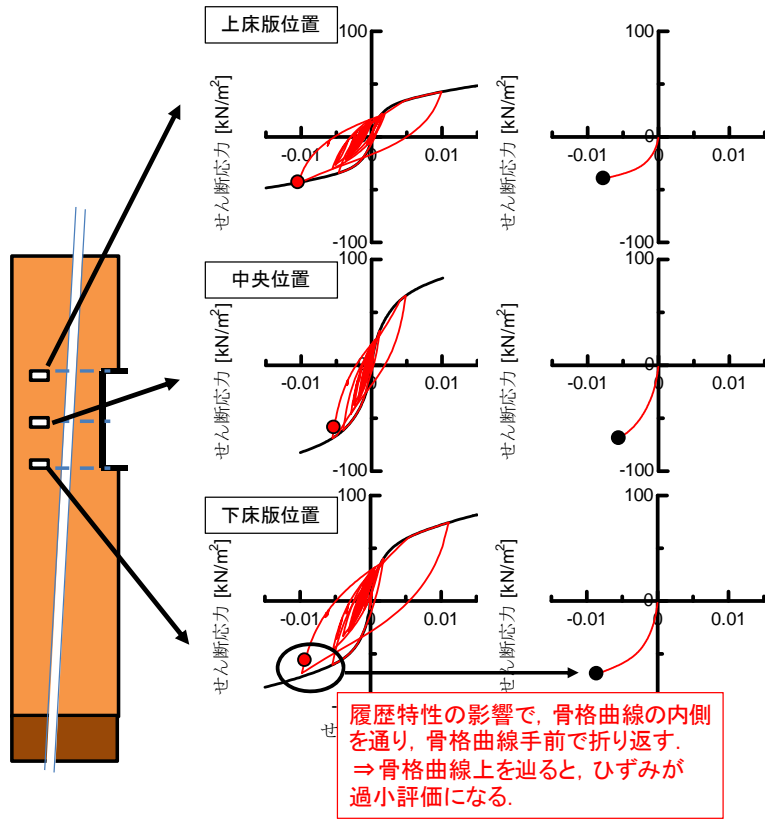

(a) 動的解析 (b) 応答震度法 Case3

図-16＼cjkstart代表深さ位置における自然地盤の応力-ひずみ関係 (最大加速度 : 850gal)
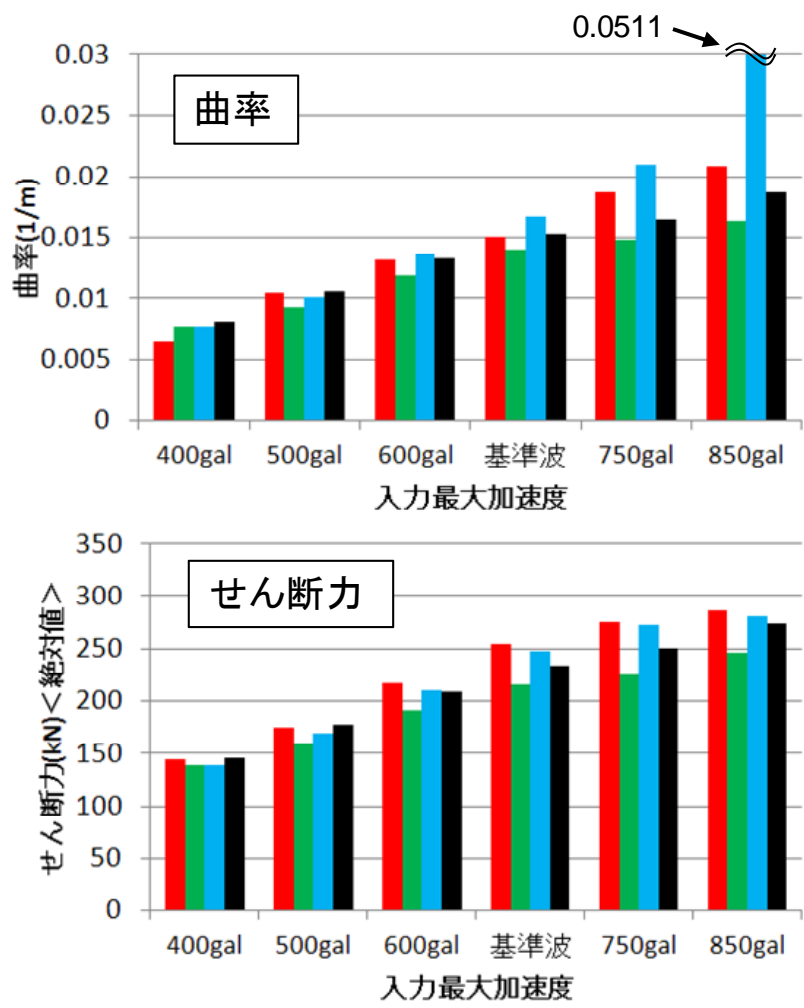

図-17 地盤の曲率，モーメント，せん断力の比較（中柱下部）

大きくなっている，つまり，地盤よりもトンネルの方が 岡性が弱く, より変形するモードになる影響で，入力加 速度によっては照査結果にも影響を及ぼすことがあるこ とを示唆している．最後に応答震度法Case3については, 加速度がある程度小さい場合には曲率・断面力とも動的 解析と概小等しくなっているが，加速度がかなり大きく
なると曲率や断面力を若干過小評価する傾向にある。こ れはトンネルの変形と同様，図-16に示した地盤の非線 形モデルの影響であると考えられる.

以上の検討により，応答震度法において，地盤を非線 形として取り扱い，動的解析における着目時刻の加速度 をそのまま用いて動的解析をした場合には，トンネルの 
応答が過小評価となる危険性がある一方，地盤を等価線 形としたり，最大せん断応力に基づいて加速度を修正し て応答震度法を適用する方法を用いることで応答震度法 の精度が向上することがわかった。ただし，それぞれの 方法の検討結果より，解析精度は地盤と構造物の岡性比 や地盤応答の履歴形状にも左右されると考えられること から，入力地震動や地盤条件によっても異なる傾向が出 る可能性がある. また，駅部のようにトンネル高さが高 い場合にはトンネル下部位置における摇れ戻しの影響が さらに大きくなることが考えられるため, 今後はこれら のパラメータを変えた検討を実施し，応答震度法の適用 性についてさらに検討していきたいと考えている.

\section{6. まとめ}

本検討では，開削トンネルのFEM系静的解析法の一種 である応答震度法において，地盤の非線形性や加速度の 設定方法がトンネルの応答に及ぼす影響について，動的 解析との比較により解析的検討を行った. 得られた成果 を以下に示す.

・応答震度法において地盤を非線形として取り扱 い，動的解析における着目時刻の加速度をその まま用いて動的解析をした場合には，自然地盤 のせん断ひずみが過小評価となるため, トンネ ルの応答も動的解析に比べて小さくなる危険性 がある．特に地盤の塑性化が大きく進行するケ 一スではその傾向が強いため，地盤を非線形と した場合の応答震度法については，取り扱いに 注意が必要である.

・応答震度法における地盤を等価線形として設定 した場合には，地盤を非線形として扱った場合 に比べて最終ステップに至るまでの地盤のせん 断剛性が過小に評価され，トンネルの応答にも 影響を及ぼす。ただし，今回のケースではトン ネルの応答を $10 \%$ 程度過大に評価する程度であり，
耐震の評価結果にほとんど余裕がないような場 合を除けば，十分有用であると思われる.

- 最大せん断応力から換算した加速度を用いるこ とにより，地盤を非線形とした応答震度法でも， 動的解析の着目時刻における応答を概ね再現す ることができる。ただし，地盤の履歴形状によ っては精度が少し悪くなる可能性があり，適用 に注意が必要である.

今後, 地盤条件や構造物条件を変えた検討を追加して 実施し, 応答震度法の適用性についてさらなる考察を行 う予定である。

\section{参考文献}

1)（財）鉄道総合技術研究所：鉄道構造物等設計標 準・同解説 而震設計, 1999.

2) 日本道路協会：駐車場設計施工指針 - 同解説， 1992.

3) 室谷耕輔, 西山誠治, 西村昭彦: 多層開削トンネル の耐震設計における応答変位法の適用性の検討およ び地盤ばねの検討, 第 9 回トンネル工学研究発表会, pp.343-348， 1999.

4) 片山幾夫, 足立正信, 嶋田穣, 都築富雄, 瀬下雄 一：地下埋設構造物の実用的な準動的解析法「応答 震度法」の提案, 第 40 回土木学会年次学術講演会講 演概要集第 1 部, pp.737-738, 1985.

5) 立石章: 静的 FEM を用いた地中構造物横断面方向の 耐震計算法における地震荷重の作用方法の研究, 土 木学会論文集, No.519/I-32, pp.139-148， 1995.

6)（株）佐藤工業 : 神戸高速鉄道東西線 大開駅災害復 旧の記録, 1997 .

7) 矢的照夫, 梅原俊夫, 青木一二三, 中村晋, 江岦順 一：兵庫県南部地震による神戸高速鉄道・大開駅の 被害とその要因分析, 土木学会論文集, No.537/I-35, pp.303-320, 1996.

8) 野上雄太, 室野剛隆 : S 字型履歴曲線を有する土の非 線形モデルとその標準パラメータの設定, 土木学会 地震工学研究発表会論文集, Vol.30, 2009.

(2011.12.15受付、2012.3.3修正、2012.3.6受理)

\section{A STUDY ON PRECISION OF STATIC ANALYSIS USING CALCULATION OF RESPONSE OF CUT AND COVER TUNNEL}

\section{Tomohiro KAWANISHI, Junji KIYONO and Seiji NISHIYAMA}

In railway seismic design of cut and cover tunnel, the static analytical method called 'Seismic deformation method', is generally used. This method, however, has a problem on accracy of calculation of coefficients of interaction springs. On the other hand, analysis methods used the FEM models were also developed by some researchers. We can calculate responses of cut and cover tunnels by using these methods more accurately. In this paper, we consider about the precision of the static analytical method using FEM model called 'Ground response acceleration method' by comparing the responses with ones obtained from the dynamic analyses. 